\title{
Negotiating a Shared Psychological Contract with Students
}

\author{
Charlotte Pietersen \\ Department of Business Management, \\ University of Limpopo, Turfloop Campus, Sovenga, 0727, Republic of South Africa \\ charlotte.pietersen@ul.ac.za
}

Doi:10.5901/mjss.2014.v5n7p25

\begin{abstract}
This article explicates how a shared psychological contract was negotiated with senior undergraduate students at the beginning of a new academic year. The guiding idea behind the investigation is that students' voice should be heard when mutual role expectations associated with the lecturer-student relationship are clarified and agreed upon. This provides lecturers with an excellent opportunity to reflect on how to adapt their behaviour to optimize the lecturer-student relationship. The Nominal Group Technique was adapted to collect data from individual students and to reach group consensus about the content of the agreement. General themes representative of individual students' shared expectations about the role of the lecturer and their own roles were identified. The entitlement beliefs and obligations of students and their professor were rated and incorporated into a psychological contract that was subsequently adopted by both parties. The findings show that senior undergraduate students (individually and as a group) have realistic ideological, transactional and relational expectations at the commencement of a new teaching year, and that the negotiation of a collective agreement is a viable option. Such agreements should be renegotiated at critical junctures during the academic year to regulate and manage mutual role expectations in the lecturerstudent relationship.
\end{abstract}

Keywords: Psychological contract, lecturer-student relationships, role expectations, entitlements, obligations

\section{Introduction}

Limited research has so far been conducted on the process of negotiation of psychological contracts in higher education contexts (Koskina, 2013: 1020). In addition, empirical evidence about the development and content of a psychological contract between a teaching-active lecturer and a group of senior undergraduate students is not readily available. Researchers predominately focus on psychological contracts with first year students (Bryson, McDowell, McGugan \& Sanders, 2009). Psychological contract research has also been conducted to determine how the contract is perceived by post graduate students and academics (Koskina, 2013), and what the entitlement beliefs and expectations of students are with regards to their future employment (Gresse, 2012). The present study therefore contributes to the psychological contract literature by reporting on the process and outcomes of negotiation an agreement with senior undergraduate students in the class room context to clarify mutual role expectations.

The aim of the present study was to negotiate a shared psychological contract a new class group of senior undergraduate students. The objectives of the study are to:

- Identify individual students' expectations about their roles and the role of their lecturer in the lecturer-student relationship.

- Categorize a class group's perceptions about entitlement beliefs and obligations pertaining to the roles of students and their lecturer in the lecturer-student relationship.

\section{Literature Review}

\subsection{Role expectations}

Traditionally lecturers acted out their teaching roles by making use of transmission style lectures which are characterized by one-way communication. Students were passive receivers of knowledge and their contributions to understanding good teaching were largely ignored (Tam, Heng \& Jiang, 2009: 147). In the contemporary classroom the focus is on a collaborative learning (Läänemets, Kalamees-Ruubel \& Sepp, 2012) and honouring the voice of students (Deakin, 
McCombs \& Haddon, 2007). Much emphasis is also placed on the vital role that the lecturer/professor-student relationships play in successful teaching and learning endeavours (Meyers, 2008).

Most teaching-active academics deal with a weekly interface with students in the classroom. One of the primary features of this environment is the lecturer-student relationship (Stearns, 2001). The development and nurturing of this partnership provides a foundation for excellence and positive student outcomes, including encouraging students to take responsibility for their own learning goals on a week-to-week basis (Fisher \& Miller, 2008). Ullah and Wilson (2007) emphasise the centrality of the lecturer-student relationship as well as a positive classroom climate to promote students' motivation and academic achievement. Lecturers should build trust and mutual respect and provide support and affirmation (Deakin, et al., 2007). They also recommend that the student voice should be honoured and that positive peer relationships should be developed to provide peer support. The lecturer-student relationship is therefore conceptualized as a social exchange.

According to Sánchez, Martinez-Pecino, Rodrígues and Melero (2011: 491), one of the two major approaches used to investigate the main elements of the lecturer-student relationship is to analyze the interactive nature of the relationship. This could be accomplished by focusing on, among others, how role expectations and beliefs that underlay implicit and explicit expectations, shape the lecturer's role. The same argument applies to the role of the student.

Robbins, Judge, Odendaal and Roodt (2009: 221, 222) define a role as "... a set of expected behaviour patterns attributed to someone occupying a given position in a social unit' and role expectations as '... the way others believe you should act in a given situation'. Roles are structured, pre-defined and linked to a specific position in a given context. Role behaviour patterns can be modified based on what others expect of the role player in a specified situation. In situations in which role expectations are unclear role players may experience role ambiguity. One of the main reasons for role ambiguity is that one is unsure about expected role behaviour (Pekdemir, Koçoğlu \& Gürkan, 2013). It is therefore imperative to define the role expectations attached to each role in the context in which the roles are played out. One way to accomplish this task is to negotiate a psychological contract (Robbins, et al., 2009).

\subsection{The psychological contract}

The term psychological contract was coined by Argyris (1960). Most scholars define the concept by alluding to the employee-employer relationship. In the work context psychological contracts are viewed as the foundation of employment relationships (Rousseau, 1995; Shore \& Tetrick, 1994). They provide an explanatory framework for understanding and elucidating implicit and explicit expectations about employment relationship (Rousseau, 1990; Rousseau, 2001; Rousseau, 2004; Rousseau \& Tijorwala, 1998) and are used to regulate and manage role expectations (Nel, Van Dyk, Haasbroek, Schultz, Sono \& Werner, 2011).

While the psychological contract is usually defined as an agreement negotiated between an employee and employer, it should be noted that the employee and employer are not the only role players in organizations. Every member of an organization including managers, supervisors, subordinates and co-workers has their own expectations about the assorted work relationships and roles in the work context (Shein, 2010). Context-specific differences are also important for the creation and evaluation of psychological contracts. In the academic context psychological contracts are practical tools that academics can use to clarify the expectations of students and themselves (Clinton, 2009).

The concept of a psychological contract can be explained from three different perspectives. Firstly, in the contemporary human resource management literature there is a preference to define the concept by including the perceptions of both the employee and the employer (Nel, et al., 2011). Hence, contemporary psychological contracts are (usually unwritten) exchange agreements in which employees' expectations of their employer as well as the employer's expectations of individual employees are articulated (Grobler, Wärnich, Carrel, Nobert \& Hatfield, 2006; Robbins, et al., 2009). Secondly, some scholars approach the contract from the employer's perspective only (Guest \& Conway, 2002; Shore \& Coyle-Shapiro, 2003). Thirdly, Rousseau, one of the most influential exponents of psychological contracts, focuses on the perceptions of the individual employee. According to Rousseau (1995: 2), '...when an individual perceives that the contributions he or she makes obligates the organization to reciprocity (or vice versa), a psychological contract emerges.'

Rousseau's conception of the psychological contract makes provision for negotiating role obligations. This view is shared by scholars, such as Spies, Bentley, Bouldin, Wilson and Holmes (2009), Robinson, (1995), and Shore and Tetrick (1994). This tendency is also evident in the academic context. Regan (2012: 21) states that students and lecturers (in their teaching role) both have role obligations within the learning and teaching relationship. These role obligations are derived from the functions of the roles that each party plays in the student-lecturer relationship. Lecturers have to use their professional knowledge and skills to facilitate learning for students, and the function of students is to participate 
optimally in all aspects of their learning.

However, contemporary psychological contract theory has expanded to make provision not only for obligations but also for the entitlements beliefs of employees (Claes, 2005; Gresse, 2012; Guest, 2004). Psychological contracts may include an unspecified number of entitlements beliefs and obligations (Guest, 2004; Nel, et al, 2011). It is therefore unrealistic to list generic expectations that should be include in the contract.

For the purpose of the present study the following definition of the psychological contract has been adopted. Psychological contracts are '... individual beliefs, shaped by the organisation, regarding terms of an exchange agreement, between individuals and the organisation' (Rousseau, 1995: 10). A psychological contract was negotiated to explicate the implicit and explicit role expectations related to the lecturer-student relationship from the perspective of a new class group of students who met their professor/lecturer for the first time in the classroom context.

\subsection{Negotiating a psychological contract in a new lecturer-student relationship}

In the workplace psychological contracts are negotiated and renegotiated at critical junctures in the employment relationship (Thomas \& Anderson, 1998). The first critical moment in the employment relationship is when a new employee joins an organization (Grobler, et al., 2006). New employees normally have unrealistically high expectations towards the employer and lower expectations of themselves (Rousseau, 1995). Negotiating a psychological contract with a new employee is therefore crucial to establish realistic and fair expectations.

The first critical juncture in the lecturer-student relationship is the first class contact session between the lecturer and students at the beginning of a new academic year. Perlman and McCann (1999) asked students to describe the most useful things professors do on the first day of class. The most frequently mentioned useful behaviours were, providing detailed information about the course content and requirements, and clarifying expectations.

Lecturers and students approach their courses with a variety of implicit and explicit expectations at the commencement of the teaching cycle (Fisher \& Miller, 2008: 191). Role expectations which are based on implied or explicit promises should therefore be clearly verbalized and clarified (Grobler, et al., 2006; Spies, et al., 2009). The voice of both the lecturer and the students involved in negotiating the psychological contract should be heard. They need to discuss the students' expectations thoroughly. This empowers both parties by providing them with an opportunity to influence, define and shape the relationship. It also helps them to arrive at and adopt a mutually acceptable agreement. The benefit of asking students to articulate their own role expectations and the expectations that they hold about the role of their lecture to one another, and to the lecturer, is that it can reduce insecurity, raise awareness of unreasonable or misguided expectations, and set the stage to establish ground rules for the lecturer-student relationship (Regan, 2012).

The two parties involved in negotiating a psychological contract should deliver on the promises they make because both parties accept and rely on these reciprocal promises about how roles will be played out in their relationship (Freese \& Schalk, 2008). When role players perceive a psychological contract as fair it has a positive impact on trust and loyalty (Fox, 1974; Wilkens \& Nermerich, 2011). Perceived unfairness could lead to feelings of disappointment and resentment (Morrison \& Robinson, 1997). This in turn could result in contract violations. Violation of the psychological contract directly affects trust between the employee and the organization (Jafri, 2012). It is therefore important that both the lecturer and the students accept and honour the negotiated agreement.

\subsection{Focus of the psychological contract in the lecturer-student relationship}

A psychological contract is normally negotiated to cater for the needs of the individual (Argyris, 1960; Rousseau, 1995) and each psychological contract is therefore unique. However, Rousseau (2001) makes provision for not only negotiating idiosyncratic contracts but also for negotiating collective agreements with groups of employees with common perceptions. Rousseau and Greller (1994) attribute the need for shared psychological contracts to the group subcultures that develop over time in a specific work context.

The rationale for negotiating a shared psychological contract with students is based on the unique values of the current generation of students. They form part of the so-called generation Y or 'Millennials' (Nel, et al., 2011). One of the characteristic of this generation is that they value collective action. According to Gibson (2009), they need structure, they love being team players, they accept authority, they usually follow rules, and they want their voice to be heard. Negotiating a shared psychological contract provide students with an opportunity for collaboration with the lecturer and their peers, and for their voice to be heard.

Various typologies have been developed by scholars such as Rousseau (1995), Shore and Barksdale (1998), Guest (1998), Rousseau and Schalk (2000), and Janssens, Sels and Van den Brande (2003) to distinguish between 
different types of psychological contracts. For the purpose of the present study only Rousseau's typology is highlighted. She distinguishes between transactional contracts and relational contracts. Transactional contracts are negotiated in short-termed employment relationships. They focus on economic rewards, and performance requirements and expectations are explicitly formulated (Freese \& Schalk, 2008). Relational contracts, on the other hand, are more openended and mutual expectations are less clearly specified. They are agreed upon to establish and maintain long-term relationships based on emotional involvement as well as financial rewards, loyalty, commitment and trust, and development and training opportunities (Aselage \& Eisenberger 2003; Van den Brande, Janssens, Sels \& Overlaet, 2002; Yan \& Zhu, 2003). Both types of contract can exist in one employment relationship (Scheepers \& Shuping, 2011).

McLean Parks, Kidder and Gallagher (1998) use elements of Rousseau's typology in their discussion of the focus of psychological contracts. According to them, focus in a psychological contract refers to '... the relative emphasis on socio-emotional versus economic concerns' (McLean, et al., 1998; 711). Performance requirements and expectations paramount in the lecturer-student relationship and a psychological contract between a lecturer and students is geared toward truthfulness, sharing, respect and development opportunities instead of focusing on material and monetary rewards.

\section{Method}

\subsection{Population and sample}

Universities in South Africa offer Bachelor and Honours degrees at undergraduate level, and Masters and Doctorate degrees at postgraduate level. A single case study mixed method design was utilized to gather qualitative and quantitative data from the target population of students. Twenty-five of the twenty-seven students registered for one of the five year-long modules that form part of an Honours degree program participated in the study.

An offer was made to students to participate in an activity aimed at negotiating an agreement about their expectations during their first class contact session on 31 January 2014. The purpose of the exercise was explained to them and they were informed that their identity would be kept confidential, that their participation is voluntary, and that the information obtained would be used for research purposes as well as for regulating and managing their expectations.

\subsection{Data collection}

A modified version of the Nominal Group Technique (NGT), developed by Delbecq and Van de Ven (1971), was applied to obtain individual and grouped data and to gain group consensus about the content of a shared psychological contract. The NGT is a mixed method approach for gathering both qualitative and quantitative data and to reach group consensus (Potter, Gordon \& Hamer, 2004).

Three custom-made forms were designed to obtain individual and group responses in a two-hour long meeting between the researcher/professor and the student cohort. The three forms were distributed consecutively.

Forms $A$ and $B$ were used to capture students' first person descriptions of their expectations in their own words and from their unique point of view. The question asked on Form A is: What do you expect from your lecturer? On form B students responded to the question: What can your lecturer expect from you? The lecturer read the question stated on Form A and asked students to write down their responses in as much detail as possible. They had to work silently and independently. The same procedure was followed with Form B.

Form $\mathrm{C}$ is divided into four cells. This form was used to focus on the specific entitlement beliefs and obligations of the students. Each student had to compile lists of their rights and responsibilities, and the rights and responsibilities of their lecturer. Again they had to work silently and independently.

The class group was then divided into four small groups of five students each to allow sub-groupings of students in the class to reach consensus about to lists that they have compiled individually. They were instructed to discuss their individual responses, reach consensus, and to collate and record their group's perceptions about their rights and responsibilities and the rights and responsibilities of their lecturer on a flipchart.

The lecturer collected all the questionnaires and collated the four group products into one document. Individual items in the document were discussed in detail for clarification and shared meaning. This activity also provided an opportunity member checks (to establish the trustworthiness of the data by verifying that the items listed truly reflect the expectations of the whole class group).

Finally, pooled ratings of the rights and responsibilities of the students and the rights and responsibilities of the lecturer were listed in a shared psychological contract. Both parties then adopted the agreement. 


\subsection{Data analysis}

Data analysis was conducted during the data collection process as well as immediately after data collection as recommended by Fisher and Miller (2008) and Thorne (2003) in order to provide the lecturer with an opportunity to implement changes to the teaching process based on the students' expectations and to give aggregated feedback to the group.

The texts compiled by the individual students were analyzed qualitatively. According to Creswell (1994), there is no single correct method for analysing qualitative data. Rather, the purpose of a study dictates the method used. In the present study an inductive approach was used to condense individual responses into general themes. According to Thomas (2003: 1), two of the main purposes for using an inductive approach are to reduce varied raw text data through repeated examination and comparison into a set of categories, and to establish clear links between the research objectives and the summary findings derived from the raw data.

The texts were transcribed by the researcher/lecturer and natural meaning units (every separate assertion expressed in words) were identified and listed for each of the respondent as recommended by (Edwards, 1991). The natural meaning units were clustered into general themes that appear to be common to all the students' descriptions. Excerpts of students' verbatim comments are used in this article to illuminate the research questions.

According to Miles and Huberman (1994), deviant or exceptional cases should be displayed in word or diagrammatical form. Therefore, each of the individual texts and the four group products were scrutinized for interesting data not captured in psychological contract.

The items in the two categories of rights and responsibilities were analyzed quantitatively. Items were numbered, individual students prioritized them, and the ratings were pooled. The most important item in each of the lists received the highest rating and the least important one the lowest rating.

\section{Findings}

\subsection{Sample composition}

Table 1. Sample Size based on Age and Gender

\begin{tabular}{|c|c|c|c|}
\hline Male & Age & Female & Age \\
\hline & & 4 & 21 \\
3 & 21 & 4 & 22 \\
4 & 22 & 1 & 23 \\
1 & 23 & 4 & 25 \\
2 & 27 & 1 & 28 \\
& & 1 & 31 \\
\hline $\mathbf{N = 1 0}$ & & $\mathbf{N}=15$ & \\
\hline
\end{tabular}

It is evident from Table 1 that the sample the participants are Millennials and that there is slightly more females in the sample compared to males.

\subsection{General themes}

Students' general expectations of their professor were clustered into six general themes, and what their professor can expect from them are them grouped into four general themes. These themes are depicted in Table 2.

Table 2. Individual Students' Expectations

\begin{tabular}{|l|l|}
\hline \multicolumn{2}{|c|}{ What do you expect from your lecturer? } \\
\hline Theme & Description \\
\hline 1. Professionalism & Punctuality, preparedness, a role model, honesty, and fairness. \\
\hline 2. Structure & $\begin{array}{l}\text { Guidelines about the course and who to write assignments as well as clear well constructed test and } \\
\text { examination questions. }\end{array}$ \\
\hline 3. Rapport & $\begin{array}{l}\text { Approachable, maintain availability outside of class, sensitive in listening to students' concerns, and } \\
\text { encouraging students. }\end{array}$ \\
\hline 4. Respect & $\begin{array}{l}\text { Equal treatment, notify student of changes, available at designated times, respects cultural } \\
\text { differences, negotiation, tactful, allows expression of opinions. }\end{array}$ \\
\hline
\end{tabular}




\begin{tabular}{|l|l|}
\hline 5. Developmental focus & Challenging work, develop cognitive skills, preparation for future work roles. \\
\hline 6. Learning reinforcement & Clarification, self-assessment activities, formative feedback, class participation and engagement. \\
\hline \multicolumn{2}{|c|}{ What can your lecturer expect from you? } \\
\hline Theme & Description \\
\hline Conduct & Mature, well-behaved, cooperation, honesty. \\
\hline Classroom behaviour & Punctuality, undivided attention, stage fright, participation. \\
\hline Academic duties & $\begin{array}{l}\text { Hard work, good performance, responsible and accountable, dedication and commitment, willingness } \\
\text { to learn. }\end{array}$ \\
\hline Interaction & Frequent consultation, respect authority, respect decisions and rules. \\
\hline
\end{tabular}

\subsection{Additional items of interest}

Additional noteworthy items that do not form part of the negotiated agreement are listed in Table 3 in no particular order. It appears that students are willing to be punished for breaking rules, coming late to class, and for late submissions of work. They do warn their lecturer that some of them have illegible handwritings. They are also extremely aware of their future role as professionals in their field and therefore insist on dressing 'formally' for class presentations.

Table 3. Interesting Items Excluded from the Shared Psychological Contract

The lecturer has the right to:
Punish students for non-cooperation, such as tardiness in submissions and class attendance.
The lecturer can expect:
Ugly hand writing from some students.
The students will wear formal attire when they do class presentations.

\subsection{The shared psychological contract}

The specific rights and responsibilities of the students and their lecturer are listed in Table 4. A value of 1 is given to the most important item is each of the four cells in the table. The table shows that the rights and responsibilities of students and the lecturer agreed upon in the shared psychological contract are relatively equal in number.

Table 4. Ranked Rights and Responsibilities of the Students and Lecturer

\begin{tabular}{|c|c|}
\hline Students have the right to: & The lecturer has the right to: \\
\hline $\begin{array}{l}\text { 1. Receive quality education. } \\
\text { 2. Fair and equal treatment. } \\
\text { 3. Recent and relevant information regarding the subject being } \\
\text { presented. } \\
\text { 4. Consultation. } \\
\text { 5. Good feedback after assessments. } \\
\text { 6. Voice opinions. } \\
\text { 7. Participation in contact sessions. } \\
\text { 8. Privacy of scripts. } \\
\text { 9. Negotiate any changes in the program. }\end{array}$ & $\begin{array}{l}\text { 1. Be respected. } \\
\text { 2. Cooperation from students in all matters relating to the } \\
\text { learning situation. } \\
\text { 3. A dedicated attitude from students with regard to their own } \\
\text { learning and development. } \\
\text { 4. Demand punctuality in class attendance and submission of } \\
\text { assignments. } \\
\text { 5. Compile lawful and reasonable rules. } \\
\text { 6. Pose questions and demand answers in class. } \\
\text { 7. Insist on a medical certificate when a student misses an } \\
\text { assessment activity. }\end{array}$ \\
\hline Students have the responsibility to: & The lecturer has the responsibility to: \\
\hline $\begin{array}{l}\text { 1. Work hard and strive for excellence. } \\
\text { 2. Acquiring learning material. } \\
\text { 3. Contribute to a relationship of mutual respect with the lecturer } \\
\text { and co-learners and exhibit good conduct. } \\
\text { 4. Submit of assignments in time. } \\
\text { 5. Prepare for and attend classes regularly and punctually. } \\
\text { 6. To obey lawful and reasonable rules. } \\
\text { 7. Provide acceptable, valid reasons for missing a class or } \\
\text { assessment. } \\
\text { 8. Participate in learning activities. } \\
\text { 9. Inform the lecturer of problems that students might be } \\
\text { experiencing. } \\
\text { 10. Respect consultation hours. }\end{array}$ & $\begin{array}{l}\text { 1. Provide students with guidelines and relevant information. } \\
\text { 2. Provide quality facilitation by preparing well for contact } \\
\text { sessions and by using class time effectively. } \\
\text { 3. Provide effective and fair evaluation of assessment } \\
\text { activities. } \\
\text { 4. Inform students of any changes in the program or learning } \\
\text { material. } \\
\text { 5. Assist students with problems that they may experience. } \\
\text { 6. Contribute to a relationship of mutual respect. } \\
\text { 7. Respect consultation hours. } \\
\text { 8. Provide correct and timely feedback on assessments. }\end{array}$ \\
\hline
\end{tabular}




\section{Discussion and Conclusion}

The negotiated psychological contract contains a mixture of ideological, transactional and relational expectations. These findings support Koskina's (2013) findings about the expectations included in an exchange agreement between students, their tutors and their learning institution.

The students' ideological expectations include that they want to receive quality education, and fair and equal treatment. In the words of two of the students: 'My goals or ambitions are to be a responsible young man, acquire more knowledge and develop my mind in general and I hope my lecturer give me and my class mates the best education that money can buy' and 'We want good and equal treatment with no favouritism'.

Specific transactional expectations as well as more open-ended relational expectations (with the exception of monetary rewards in both instances) are contained in the general themes and in the different categories of rights and responsibilities in the psychological contract. Performance requirements include lecturer professionalism, structure, learning reinforcement and students' academic duties. Performance requirements are listed in all four cells of the psychological contract (Rights of students: Ratings 3, 4, 5, 7 and 8; Responsibilities of students: Ratings 1, 2, 3, 4, 7 and 8; Rights of the lecturer: Ratings 4, 5, 6 and 7; Responsibilities of the lecturer: Ratings 1, 2, 3, 4, 7, and 8).). Students' expectations with regard to their transactional entitlement beliefs and obligations are highlighted by some of their comments, for example, I have the right to participate in the classroom, to ask; We should have timely and fair test feedback and please do not let the other students see my marks!; Do we have the right to negotiate? Something I would really appreciate from my lecturer is to be a little lenient when giving us some work to do because we are doing five modules so it will really be too much considering what the other lecturers impose on us; I will make sure that I come to class regularly and I will not be late and I will let you know why I am late in doing my work; I will submit my assignment on time and they will not be sloppy work; I will obey any lawful command as long as it is fair and not against the rules.

Their beliefs about transactional entitlements and obligations of their professor are reflected in the following selection from their writings. Time is very important and scarce. I expect my lecturer to be on time in class; That she prepare lectures before lectures. This will enable her to prepare the correct and essential in the module that will benefit us; She should act as a model unto which I could look up; Thorough guidelines and directions to succeed in my course and provide guidelines on how to answer questions and do assignments as different lecturers have different expectations; I would like for you to give us few questions to answer at the end of each lecture to keep us on our toes.

Thematic relational expectations included rapport, respect, a development focus as well as students' conduct, classroom behaviour and interaction. Specific relational expectations are listed in the four cells of the psychological contract (Students' rights: Ratings 4, 6 and 9; Students' responsibilities: Ratings 1 and 3; Lecturer's rights: Ratings 1, 2 and 3; Lecturer's responsibilities 5 and 6). Examples of students' relational expectations are: I will always respect your and behave like a mature human being; We need a chance to express our ideas and to voice our opinions; As for class participation, I believe it would work best if you just ask questions and point at anyone of use because it is not like we don't know the answers, it is the courage to volunteer; If it is not too much to ask for, I was hoping that you could also provide us with tests on Blackboard, all to keep our minds busy.

The relational entitlements and obligations of the professor are highlighted by the following student comments: She must respect us as much as we her and understand that we come from different backgrounds and then students will enjoy attending classes; She should not only a facilitator but also a mother and we her own children. She must always be there for us. I don't want to be scared to go to her office to consult about issues that we do not understand; One other thing that I do expect from my lecturer is to be easy to talk to, simply nice and very good in class and when I come to her for consultation; She should not be hot tempered and shout when we ask questions or have a problem but rather be very patient; Most lecturers just render their academic duties. I would love and expect to have a sight and small personal interaction with each student. This will enhance openness and make all the periods fun with increased participation; I expect the lecture to make me feel accommodated in class so that I can feel welcome and not shy and uncomfortable; My goals or ambitions are to be a responsible young man, acquire more knowledge and develop my mind in general and I hope my lecturer will help me to achieve that.

Research findings show new role players normally have unrealistically high expectations towards an authority figure and lower expectations of themselves (Rousseau, 1995). However, in the present study the students' expectations were surprisingly reasonable and well articulated as can be seen from the above excerpts. The findings of the study also provides evidence that the notion that a psychological contract only refers to perceptions of obligations has to be expanded make provision for entitlements beliefs too, as indicated in cited literature in this article.

The findings support the idea of negotiating a shared psychological contract instead of an individual contract with each individual student. The specific entitlements and obligations in the shared psychological contract are reflected in the 
assembled themes. Lecturers can therefore save time by negotiating a shared agreement.

However, according to Gibson (2012), students who form part of the $Y$ generation want structure and they have a preference to work in groups. The process followed in the present study provided structure to the students and streamlined the process of negotiating an agreement. The advantage silently generating ideas is that the respondents can take their time to reflect on and reconstruct detailed responses on their own without interferences from the researcher or their co-respondents (Potter, et al., 2004). The students, all of them Millennials, also used their individual reflections as a basis to participate in group discussions. This allowed for more comfortable interaction and more open and informed communication with their peers.

The process of asking students to express to themselves, their peers and their professor what their expectations are at the beginning of a new academic year provide an excellent opportunity to lecturers to reflect on how to adapt their behaviour to optimize their relationship with their students. It also provides a first opportunity to demonstrate to students that lecturers are willing to listen to their voice. For students it provides a chance to reflect on what they want from the lecturer-student relationship, and to take ownership and co-responsibility for their behaviour in the relationship.

It is recommended that follow-up discussions should be held, for example, at the end of the first semester to determine if contract violations took place and to reinforce the lecturer-student relationship in the second semester as recommended by Fisher and Miller (2008).

\section{References}

Argyris, C. (1960). Understanding organizational behaviour. : Dorsey: Homewood.

Aselage, J. \& Eisenberger, R. (2003). Perceived organizational support and psychological contracts: a theoretical integration. Journal of Organizational Behaviour, 24(5): 491-509.

Bryson, C., McDowell, L., McGugan, S., Sanders, G. (2011). A relationship heading for divorce? assessment, trust and student engagement. [online] Available: http://www.brookes.ac.uk/aske/documents/bryson_mcdowell.pdf

Cleas, R. (2005). Organization promises in the triangular psychological contract as perceived by temporary agency workers, agencies, and client organizations. Employee Responsibilities and Rights Journal, 17 (3): 131-142.

Clinton, M. (2009). Managing students' and teachers' expectations of Higher Education: A psychological contract approach. School of Social Science and Public Policy: King's College London.

Creswell, J. W. (1994). Research design: qualitative and quantitative approaches. Thousand Oaks: Sage.

Deakin, C. R., McCombs, B. \& Haddon, A. (2007). The ecology of learning: Factors contributing to learner centred classroom cultures. Research Papers $n$ Education, 22:3.

Delbecq, A L \& Van de Ven, A. H. (1971). A group process model for problem identification and program planning. Applied Behavioural Research, 7: 466-491.

Edwards, D. J. A. (1991). Dequesne phenomenological research method as a special class of case study research. In Van Vuuren R. Dialogue beyond polemics. Pretoria: HSRC.

Fisher, R. \& Miller, D. (2008). Responding to student expectations: a partnership approach to course evaluation. Assessment and Evaluation in Higher Education, 33 (2): 191-202.

Fox, A. (1974). Beyond contract: work, power and trust relations. London: Faber and Faber.

Freese, C. \& Schalk, R. (2008). How to measure the psychological contract? a critical criteria-based review of measures. South African Journal of Psychology, 38 (2): 269-286.

Gibson, S. E. (2009). Enhancing intergenerational communication in the classroom: recommendations for successful teach-student relationships. Nursing Education Perspective, 30 (1): 37-39.

Greese, W. G. (2012). The pre-entry psychological contract: exploring expectations and normative entitlements of student groups. [online] Available: http://hdl.handle.net/10394/9043

Grobler, P., Wärnich, S., Carrel, M.R., Nobert, F. E. \& Hatfield, R.D. (2006). Human resource management in South Africa (3rd Ed.). Thomson: UK.

Guest, D. (2004). The psychology of the employment relationship: an analysis based on the psychological contract. Allied Psychology: An International Review, 53 (4): 541-555.

Guest, D., \& Conway, N. (2002). Communicating the psychological contract: an employer perspective. Human Resource Management Journal, 12 (2): 22- 38.

Jafri, M.H. (2012). Influence of psychological contract breach on organizational citizenship behaviour and trust. Psychological Studies, 57: 29-36.

Janssens, M., Sels, L. \& Van den Brande, I. (2003). Multiple types of psychological contracts: a six-cluster solution. Human Relations, 56 (11): 1349-1278.

Koskina, A. (2013). What does the student psychological contract mean? Evidence from a UK business school. Studies in Higher Education, 38 (7): 1020-1036.

McLean P. J., Kidder, D. L. \& Gallagher, D. G. (1998). Fitting square pegs into round holes: mapping the domain of contingent work arrangements onto the psychological contract. Journal of Organizational Behavior, 19, 697-730. 
Läänemets, U., Kalamees-Ruubel, K. \& Sepp, A. (2012). What makes a good teacher? voices of Estonian students. Delta Kappa Gamma Bulletin, 79 (1): 27-31.

Meyers, S. A. (2008). Working alliance in collage classrooms. Teaching of Psychology, 35: 29-32.

Miles, M. B. \& Huberman, A.M. (1994). Qualitative data analysis (2nd E.). Newbury Park, CA: Sage.

Morrison, E. W. \& Robinson, S. L. (1997). When employees feel betrayed: a model of how psychological contract violation develops. The Academy of Management Review, 17: 3-20.

Nel, P. S., Van Dyk, P. S., Haasbroek, G .D., Schultz, H. B., Sono, T. \& Werner, A. (2011). Human resources management. (8th Ed). Southern Africa: Oxford University Press.

Pekdemir, I., Koçoğlu, M. \& Gürkan, G. C. (2013). The effects of harmony of family, distributive justice, and role ambiguity on family member impediment: the mediating role of relationship conflict and an example of developing country Turkey. Asian Social Science, 9 (9).

Perlman, B. \& McCann, L.I. (1999). Student perspectives on the first day of class. Teaching of Psychology, 26: 277-279.

Potter, M., Gordon, S. \& Hamer, P. (2004). Nominal group technique: a useful consensus method in physiotherapy research. NZ Journal of Physiotherapy, 32 (3): 126-130.

Regan, J. (2012). The role obligations of students and lecturers in higher education. Journal of Philosophy of Education, 46 (1): $14-24$.

Robinson, S. L. (1996). Trust and breach of the psychological contract. Administrative Science Quarterly, 41 (December): 574-599.

Robbins, S. P., Judge, T. A., Odendaal, A. \& Roodt, G. (2009). Organisational behaviour: global and Southern African perspective. Cape Town: Pearson Education.

Rousseau, D. M. (1990). New hire perceptions of their own and their employer's obligations: a study of psychological contracts. Journal of Organizational Behavior, 11: 389-400.

Rousseau, D. M. (1995). Psychological contracts in organizations. Thousand Oaks, CA: Sage.

Rousseau, D. M. (2001). The idiosyncratic deal: flexibility versus fairness. Organizational Dynamics, 29: 260-273.

Rousseau, D. M., \& Greller, M. M. (1994). Human resource practices: administrative contract makers. Human Resource Management, 33(3): 385-401.

Rousseau, D. M. \& Schalk, R. (2000). (Eds.) Psychological contracts in employment: cross-national perspectives. Thousand Oaks, CA: Sage.

Rousseau, D. M. \& Tijoriwala, S. (1998). Assessing psychological contracts issues. alternatives and measures. Journal of Organizational Behaviour, 19: 679-696.

Sander, P., Stevenson, K., King, M. \& Coates, D. (2000). University students' expectations of teaching. Studies in Higher Education, 25, 309-323.

Sánchez, M. M., Martinez-Pecino, Rodrígues, Y. T. \& Melero, P. T. (20122). Student perspectives on the university professor role. Social Behavior and Personality, 39 (4): 491-496.

Scheepers, C. \& Shuping, J. (2011). The effect of human resource practices on psychological contracts at an iron ore mining company in South Africa. SA Journal of Human Resource Management, 9(1): 302-320.

Schein, E. H. (2010). Organizational culture and leadership. (4th Ed.). San Francisco, Ca: Jossey-Bass.

Shore, L. M. \& Barksdale, K. (1998). Examining the degree of balance and level of obligation in the employment relationship: a social exchange approach. Journal of Organizational Behavior, 19:731-744.

Shore, L. M. \& Coyle-Shapiro, J. A. M. (2003). New developments in the employee-organization relationship. Journal of Organizational Behavior, 24 (5). 443-450.

Shore, L. \& Tetrick, L. (1994). The psychological contract as an explanatory framework in the employment relationship, in Cooper, C. L. \& Rousseau, D. M. (Eds). Trends in organisational behaviour, Vol 1. New York: John Wiley \& Sons.

Spies, A. R., Wilkin, N. E., Bentley, J. P., Bouldin, A.S., Wilson, M. C. \& Holmes, E. R. (2010). Instrument to measure psychological contract violation in pharmacy students. American Journal of Pharmaceutical Education, 74 (6): 1-11.

Stearns, S. A. (2001). The student-instructor relationship's effect on academic integrity. Ethics \& Behavior, 11 (3): 275-285.

Tam, K. Y.m Heng, M. A. \& Jiang, G. H. (2009). What undergraduate students in China say about their professors' teaching. Teaching in Higher Education, 14 (2): 147-159.

Thomas, D. R. (2003). A general inductive approach for qualitative data analysis. School of Population Health

University of Auckland, New Zealand. doi:10.1136/ebn.3.3.68

Thomas, H.D.C. \& Anderson, N. (1998) Changes in newcomers' psychological contracts during organizational socialization: a study of recruits entering the British Army. Journal of Organizational Behavior, 19: 745-767.

Thorne, S. (2000). Data analysis in qualitative research. Evidence Based Nursing, 3 (3): 68-70.

Ullah, H. \& Wilson, M. A. (2007). Students' academic success and its association to student involvement with learning and relationships with faculty and peers. College Student Journal, 41 (4): 1192-2012.

Van den Brande, I., Janssens, M. Sels, L. \& Overleat, B. (2002). Psychologischecontracten in Vlaanderen: "old deals"! (Psychological contracts in Flanders: 'old deals '?! Gedrag en Organizatie, 15: 355-369.

Wade-Benzoni, K. A., Rousseau, D. M. \& Li, M. (2006). Psychological contracts in faculty-doctoral student collaborations. International Journal of Conflict Management, 17 (1): 4-33.

Wilkens, U. \& Nermerich, D. (2011).'Love it, change it, or leave it' - understanding highly-skilled flexible workers' job satisfaction from a psychological contract perspective. The international Review of Management Studies, 22: 65-83.

Yan, S. \& Zhu, Y. (2013). Impact of psychological contract violation on interpersonal trust during mergers and acquisitions. Social Behavior and Personality, 41 (3): 487-496. 